behind by the posterior commissure, and a postericr pcrtion which he termed collectively the cord. He described several new nuclei in the thalamus, and illustrated his conclusions by a series of models, microscopic sections, and stereoscopic photographs of the thalamus in monkeys and rabbits.

Sir Victor Horsley dwelt on the necessity for making both horizontal and sagittal sections of the thalamus, and for directing attention to cell-systems rather than to tracts of fibres. The current system of dividing the thalamus into tracts of fibres is quite untrustworthy unless checked by the degeneration method. His excitation experiments, so far as they had gone, confirmed Dr. Mann's results.

Dr. F. Griffiths and Dr. W. B. Warrington read, an interesting paper on the varieties of the cells of the spinal ganglia and their relationship to axons of different distribution, and showed a useful series of illustrative microscopical sections.

Among many other valuable papers and discussions may be mentioned the important debate on chloroform anæsthesia and the demonstration given by Mr. Vernon Harcourt of his apparatus for the administration of known percentages of chloroform vapour. The apparatus is convenient and compact, and guarantees that the amount of chloroform administered is never in excess of 2 per cent. of the inspired air. An apparatus of a similar purpose by Dubois was also shown by Dr. Chapman.

In the section of pathology an unusual amount of valuable new work was published. The discussion on immunity was opened by the president, Dr. Ritchie, who began by pointing out what definite conclusions were now firmly established, and what were the problems which awaited solution. $\mathrm{He}$ then discussed the relation of the processes concerned in the immunity reaction to normal physiological events, and the general bearing on the question of the more important recent work. Dr. Bulloch followed, dealing in a masterly fashion with the cellular aspects of the problem of immunity, and Dr. Dreyer, of Copenhagen, read an important paper on agglutinins.

Dr. Madsen, of Copenhagen, then described the steps by which, in association with Prof. Arrhenius, he had shown that the relation of toxin and antitoxin in the living body, exemplified in what is known as "Ehrlich's phenomenon," cannot be explained, as Ehrlich holds, as being due to the presence of degenerated toxins in the crude bouillon from diphtheria or tetanus cultures. While not denying the existence of such degenerated toxins in the bouillon cultures, they maintain that the phenomenon is due to the fact that toxin possesses only a weak affinity for its corresponding antitoxin. It thus results that dissociation phenomena occur between the toxin, antitoxin, and the toxin-antitoxin molecules. In support of this view new evidence was submitted from investigations carried out upon ricin and anti-ricin, snake venom and antivenene, and saponin and its anti-body, cholesterin.

Further contributions to the study of snake venoms were communicated by Dr. C. J. Martin and Dr. Noguchi.

Dr. Wright described the experiments which led to his discovery of the bodies which he terms opsinines. These bodies have the property of enabling phagocytes to attack bacteria. They are present in the blood serum, but not in the phagocytes themselves, and they can, like anti-bodies, be transferred to foreign phagocytes, upon which they then confer a like bacteriolytic power.

At a later period of the meeting Dr. Wright gave a most lucid demonstration of the numerous brilliant modifications and new methods which he has introduced, and which simplified and much increased the accuracy of all kinds of blood investigation and research into the mechanism of bacteriolysis.

A discussion was also held upon the rôle of the lymphocyte. This was opened by Dr. Lovell Gulland and Prof. Muir, and many valuable communications were contributed, notably a paper by Dr. Beattie, of Edinburgh, in which he concluded in favour of the endothelial origin of many of the mononuclear cells in inflammation. The discussion revealed the fact that a considerably greater uniformity of opinion as to the origin of the various kinds of leucocytes is coming into existence among pathologists.

The subject of the third discussion was the chemical pathology of gout. This was opened with a most able paper from Prof. von Noorden, and in the course of the discussion NO. I 8 I 4 , VOL. 7O]
Dr. Walker Hall gave a demonstration of his simple apparatus for the rapid determination of the urinary purins.

In the section of tropical diseases Colonel Bruce opened the discussion on trypanosomiasis with a suggestive paper, in the course of which he stated that trypanosomal fever is in all probability the first stage of sleeping sickness, and that the Glossina palpalis is the medium of transmission.

A discussion was also held on the significance of the Leishman-Donovan bodies. This was introduced by Major Leishman, who pointed out the occurrence of these bodies in kala-azar, and maintained that they probably represent a stage in the life-history of a flagellate organism closely resembling a trypanosome. Dr. G. C. Low exhibited sections of the spleen from a case of kala-azar, showing these bodies in situ. He also exhibited a number of specimens showing the perivascular infiltration in the brain and cord in sleeping sickness.

Very instructive exhibits illustrating the conditions in ankylostomiasis and bilharzia infection were shown by $\mathrm{Dr}$ Armand Ruffer and by Dr. Sandwith; and Dr. Nabarro showed specimens of trypanosoma from Uganda.

In the section of State medicine the president, Dr. J. S Haldane, opened a discussion on standards of ventilation, discussing the effect upon the human system of poisonous gases and dust. The dust nuisances he considered could be better prevented by special measures, such as water sprays, than by a general increase of the ventilation. Subsequently he dealt with the effects of breathing air contaminated with an excess of carbonic acid gas, or containing a deficiency of oxygen or an increase of organic matter. The real pathological effects of such conditions, he held, were slight The discussion was continued by Dr. Jones, Dr. Oliver, Dr. Hay, and others.

Dr. Newman opened a discussion on the control of the milk supply. Having reviewed the dangers to the nation which spring from the present inadequate and contaminated milk supply, he urged that the initiative for reform must come in the first place from the consumer. So far as legislation is concerned, he thought that all that could be expected was a systematic and universal enforcement of the Dairies Order. Dr. Henri de Rothschild agreed with Dr. Newman that the demand for reform must come from the consumer. The chief difficulty appeared to him to lie in the fact that the consumer wanted good milk at a price for which only bad milk could be purchased.

\section{GEOLOGICAL NOTES.}

THE Stone Reefs of Brazil, their Geological and Geographical Relations, with a Chapter on the Cora Reefs," is the title of a memoir by Mr. J. C. Branner (Bull. Mus. Comp. Zool. Harvard Coll., vol. xliv., geological series, vol. vii.). 'These stone reefs form striking features along the Brazilian coast from near Ceará to Porto Seguro they are formed of sandstone, in places almost a quartzite, and stand flush with the water at high tide, while at low tide they are left exposed like long, low, flat-topped walls. The ports and towns behind these reefs owe their existence to them, as they form natural breakwaters, usually standing across the mouths of streams and estuaries.

In origin they are due to the solidification of beach sands. Coral reefs are now growing over and upon the stone reefs in some places, while at other places there are stone reefs overlying dead coral reefs.

Evidences of great depression and subsequent elevation occurred in late geologic times, and the sandstone reefs were formed when the land had finally risen. The author points out that in a region of concentrated rainfall and long droughts the river mouths had become temporarily closed, and the abundant aquatic and other life in the lagoons thus formed contributed to the organic acids of the waters. These waters, upon penetrating the dam of beach sand, first dissolved the carbonate of lime in it, and re-deposited this as cement when in contact with the dense sea-water on the ocean side. - In this manner some portions of the beaches have been hardened, while others have remained incoherent.

In an able article on the modes of occurrence of intrusive rocks, Mr. J. G. Goodchild discusses the question whether they displace or replace the rocks which they invade (Proc. Roy. Soc. Edin., xxv., No. 3). He cites and figures 
numerous examples which support his views that in the main the process has been one of replacement, the intrusive rock eating its way into sedimentary rock which remains undisturbed above and below; and shows no sign of having increased the thickness of the strata. In certain cases where there is evidence of some displacement or mechanical rupture in the rocks affected by igneous intrusions, he finds that the extent of the displacement is, as a rule, by no means commensurate with the volume of the rock intruded. The subject was dealt with many years ago in an article on the Whin Sill by Mr. C. T. Clough, and that author, in referring to the fact that the dolerite maintained a uniform composition, although it replaced beds of diverse mineral constitution, pointed out that these difficulties disappeared when we regarded the molten rock as having a general circulation in its mass which would lead to a uniformity in its composition. Other observers, mentioned by $\mathrm{Mr}$. Goodchild, have dealt with this interesting subject, but it has not before been so forcibly presented by an array of facts to which the author has himself largely contributed.

Figures of some notable crinoids are given in the quarterly issue of the Smithsonian Miscellaneous Collections (vol. xlv., June 15). These illustrate some notes made by Mr. Charles Schuchert, assistant curator of stratigraphic palæontology in the National Museum at Washington, who spent four months in Europe studying fossil faunas and their stratigraphic sequence in the field and in museums. He returned with "sixteen boxes of European fossils," which, as observed, will form " a good nucleus for comparative studies with the American faunas."

Prof. R. S. Tarr has directed attention to a series of artesian well borings which have been carried through the lacustrine delta deposits on which the main portion of the City of Ithaca, New York, is built. The superficial strata comprise clays 40 to 60 feet thick, beneath which are sands and gravels 20 to 70 feet, then glacial lake clays about roo feet, and at base (resting on the bedrock) a morainic series of till, sand and gravel, 80 feet or more in thickness. The greatest thickness of drift was 342 feet. Artesian water was met with in both series of gravels-that in the upper series being derived from the alluvial fans opposite the mouths of the streams that descend to the Ithaca delta. The water found in the deeper sands and gravels is believed to be derived from the moraine which occupies the Cayuga Valley, distant more than eleven miles from the sites of the wells, and at a sufficient elevation to account for a yield under pressure at one well of 300,000 gallons of water a day.

In an article on the hanging valleys in the Finger Lake region of central New York (Amer. Geol., May), Prof. R. S. 'Tarr gives reasons for his conviction that the glacial erosion theory cannot be accepted as proved in reference to that area. The land having attained a condition of topographic maturity, represented by the hanging valleys and by the gentle slopes of the main walls above the 800 -foot contour, was subjected to rejuvenation. The effects of the elevation were to increase the amount of stream erosion along the main valleys, and although a moderate amount of glacial erosion is allowed, it is not regarded as the main factor in the production of the features.

The 1902-3 eruptions of Mont Pelée, Martinique, and the Soufrière, St. Vincent, form the subject of a report by $\mathrm{Mr}$. E. O. Hovey (Comptes rendus ix. Congrès geol. internat. de Vienne, 1903). This report is based on data obtained for the American Museum of Natural History, and gives almost exclusively the result of the personal observations of the author. These have been given from time to time in NAture, especially with reference to the great "spine" which appeared on Mont Pelée. The history of the volcanoes has in the present publication been brought down to the date of printing, February I, I904.

To the Proceedings of the Geologists' Association (vol. xviii. part vii.), Miss Ethel G. Skeat contributes an article on the Jurassic rocks of east Greenland, wherein the occurrence of Rhætic-Lias and Lower Middle and Upper Oolitic fossils is noted. The finding of such definite Upper Oolitic forms as Astarte Saemanni and Aucella Pallasi is of much interest. Mr. C. D. Sherborn has prepared a useful index to the four papers on zones of the white chalk of the English roast by Dr. A. W. Rowe and himself, and this is published in the above mentioned Proceedings.

\section{UNIVERSITY AND EDUCATIONAL INTELLIGENCE.}

OxFord.-Mr. J. Henderson Smith, Balliol College, has been elected first Philip Walker student for three years. The studentship was only founded during the past year, and is for the furtherance of original research in pathology.

The long vacation course of lectures which has been arranged by the Oxford School of Geography was opened on Tuesday last by $\mathrm{Mr}$. H. J. Mackinder, the reader in geography, who delivered an address. During the present week lectures are to be given by Mr. Mackinder on "Leading Ideas of European Geography," by Mr. J. L. Myres on "The Physical Conditions of Greek Civilisation," and by the Rev. E. C. Spicer on "The Structure of the Oxford Region." Next week the lecturers will be Mr. C. R. Beazley, who will take as his subject "The Advance of Geography-Land Travel, Oceanic Exploration and Scientific Geography," and Prof. W. W. Watts, F.R.S., who will speak on "Charnwood Forest as a Study in the Origin of Landscapes."

Mrss M. STokes, PH.D., has been appointed to a demonstratorship in botany at the University of Manchester.

DR. G. SENTER has been appointed lecturer in chemistry at the St. Mary's Hospital Medical School, Paddington.

THE University of London will be represented at the International Congress of Medicine, to be held at Lisbon in April, 1906, by Sir Thomas Barlow, K.C.V.O., M.D., and Dr. A. D. Waller, F.R.S.

A RESEARCH studentship of rool. a year for two years is offered by the London School of Economics and Political Science. The examination will be held on October II and 12. Full particulars may be obtained on application to the director of the school, Clare Market, London, W.C.

WE have received a copy of the Johns Hopkins University Circular for July, which contains the programme of the courses of study for 1904-5. Next session's work will be the twenty-ninth year of instruction at this university in Baltimore, and the provision made for every class of student is remarkably complete.

Prof. W. E. Dalby has been appointed professor of civil and mechanical engineering at the Central Technical College, South Kensington, in the place of Prof. W. C. Unwin, F.R.S., resigned. Prof. Dalby has hitherto occupied the chair of mechanical engineering and applied mathematics at the City and Guilds 'Technical College, Finsbury. Applications for the filling of the latter post are invited.

THE Senate of the University of London has accepted the offer made by the Goldsmiths' Company to provide an additional sum of $5000 \mathrm{l}$. in connection with the recent gift to the university of the Goldsmiths' Institute at New Cross. This further donation of the Goldsmiths' Company will enable the university to carry on during 1904-5 at the New Cross Institute the classes of a polytechnic character which have proved very popular and useful in previous sessions. The classes to be held next winter will be arranged by the Senate in consultation with the London County Council.

THE Senate of the University of London has decided that in future internal and external candidates for the Bachelor of Science honours degree in botany, chemistry, physics, physiology and zoology must produce note-books of their laboratory work, which may include a record of any research work in which they have participated. The entries in such note-books must be duly certified by the teacher if any, and will be taken into account in estimating the qualifications of candidates, provided only that the research work be not allowed to take the place of such sound general knowledge as should be required from an honours candidate.

The Senate of the University of London and the council of University College have now agreed on the text of the Bill for the incorporation of the college in the university. The sum required before the formal transfer can actually be effected has not yet been received in full, about $18,000 l$. being still required, but steps are to be taken to deposit the Bill with the view of its introduction next session. The Drapers' Company has announced that, being satisfied with the conditions under which the incorporation is to be effected, it is prepared to pay off the debt on the college land and buildings to the extent of $30,00 \mathrm{ol}$, , on condition 